\title{
THE TREATMENT OF HISTORY IN AUSTRIAN-HUNGARIAN STATE PRIMARY SCHOOL TEXTBOOKS FOR BOSNIA AND HERZEGOVINA
}

Abstract

Following the Austrian-Hungarian occupation of Bosnia and Herzegovina, the new authorities introduced an interconfessional school system aimed at educating children in the spirit of Bosnian-Herzegovinian provincial and Habsburg civic patriotism. Existing South Slavic textbooks, containing numerous texts that were offensive to Muslims, proved unsuitable for such an undertaking. The goal of this article is to address the treatment of history in the new textbooks written for BosniaHerzegovina's state primary schools, considering both the selection of historical topics and the manner in which historical education was utilized in order to impart desirable loyalties among the students and further the government's political goals. Besides encouraging the students to identify with the glorious deeds of their medieval forefathers and thus fostering a historically based Bosnian patriotism, the textbooks were written with a clear intent to appeal to the province's Muslims and, in particular, to their gentry. They implied a clear continuity between Bosnia's medieval, supposedly Bogomil aristocracy and the contemporary Muslim elites, while also being careful not to address historical topics in a manner that may offend Muslim sensibilities. Lastly, considerable effort was invested into historically justifying contemporary Habsburg rule over Bosnia in Herzegovina and, in a wider sense, teaching the children that a benevolent foreign government may benefit a society suffering from disunity or rebelliousness.

Key words: Bosnia and Herzegovina; Austria-Hungary; nationalism; textbooks; education

OLIVER PEJIĆ Univerza $\vee$ Ljubljani, Ljubljana E-mail: pejicoliver@gmail.com

CITATION: Pejić, O. (2018). The Treatment of History in Austrian-Hungarian State Primary School Textbooks for Bosnia and Herzegovina. Sprawy Narodowościowe. Seria nowa, 2018(50). https://doi.org/10.11649/sn.1633

This work was supported by the author's own resources. No competing interests have been declared.

This is an Open Access article distributed under the terms of the Creative Commons Attribution 3.0 PL License (creativecommons.org/licenses/by/3.0/pl/), which permits redistribution, commercial and non-commercial, provided that the article is properly cited. (C) The Author(s) 2018.

Publisher: Institute of Slavic Studies, Polish Academy of Sciences 


\section{PODEJŚCIE DO HISTORII W PODRĘCZNIKACH SZKOLNYCH AUSTRO-WĘGIER \\ DLA PAŃSTWOWYCH SZKÓL PODSTAWOWYCH \\ W BOŚNI I HERCEGOWINIE}

Streszczenie

W następstwie austro-węgierskiej okupacji Bośni i Hercegowiny nowe władze wprowadziły międzywyznaniowy system oświatowy nastawiony na kształcenie dzieci w duchu patriotyzmu prowincjonalnego bośniacko-hercegowińskiego oraz obywatelskiego habsburskiego. Istniejące podręczniki południowosłowiańskie, zawierające liczne teksty, które były obraźliwe dla Muzułmanów, okazały się dla tego przedsięwzięcia nieprzydatne. Niniejszy artykuł ma na celu omówienie podejścia do historii w nowych podręcznikach napisanych dla państwowych szkół podstawowych w Bośni i Hercegowinie, biorąc pod uwagę zarówno dobór tematów historycznych jak i to, w jaki sposób edukacja historyczna została wykorzystana dla narzucenia uczniom pożądanych postaw lojalności, a następnie politycznych celów rządu. Oprócz zachęty do tego, by uczniowie identyfikowali się z chwalebnymi czynami ich średniowiecznych przodków, a tym samym zamysłu propagowania historycznie wspartego patriotyzmu bośniackiego, podręczniki te zostały napisane z wyraźną intencją, aby trafiły do zamieszkujących tę prowincję Muzułmanów, zwłaszcza ich szlachty. Implikowały widoczną ciągłość pomiędzy bośniacką średniowieczną arystokracją, zapewne bogomilską, a współczesnymi elitami muzułmańskimi, przy czym starannie unikały odniesienia do tematów historycznych, w sposób który może obrażać wrażliwość Muzułmanów. Wreszcie, z dużym nakładem pracy dążyły do tego, by historycznie uzasadnić ówczesne rządy Habsburgów w Bośni i Hercegowinie oraz, w szerszym sensie, wpoić dzieciom wiedze o tym, że łagodne obce rządy mogą dobrze przysłużyć się społeczeństwu cierpiącemu na brak jedności i buntowniczemu. [Transl. by Jacek Serwański]

Słowa kluczowe: Bośnia-Hercegowina; Austro-Węgry; nacjonalizm; podręczniki szkolne; edukacja

\section{THE TEXTBOOK CONTROVERSY IN BOSNIAN-HERZEGOVINIAN STATE SCHOOLS}

ntroducing an interconfessional school system into a society where schools were traditionally characterised by confessional separation proved no simple task for Bosnia and Herzegovina's new Habsburg authorities. The province had inherited from the Ottoman period a parallel system of Muslim, Orthodox, Catholic and Jewish confessional schools, each of which had primarily served the needs of its respective religious community. These schools taught the children different literary languages and employed separate sets of textbooks. ${ }^{1}$

The Habsburg authorities expected that the confessional schools would soon "die out" in the face of competition from higher-quality state schools (Bogićević, 1965, p. 148). Although almost all Catholic schools did eventually transform into state schools

\section{-....}

The fundamental monographic, albeit in certain aspects dated works on education in Bosnia and Herzegovina during the Ottoman and Habsburg periods remain V. Bogićević (1965) and M. Papić (1972). For Muslim schools in particular, see H. Ćurić (1983), for Catholic schools Papić (1982) and for Orthodox schools Papić (1978). Regarding the question of language in the schools, see M. Grčević (2015), E. Solak (2014) and M. Šator (2004). The Muslim schools, with the exception of a few vernacular-language textbooks printed in the Arabic script, employed Arabic textbooks (Ćurić, 1983, pp. 40-42). The Orthodox schools primarily used Cyrillic textbooks imported from Serbian schools in neighbouring lands (Papić, 1978, p. 72) and the Catholic schools used Latin-script textbooks either imported from neighbouring Croatia or printed in Bosnia and Herzegovina (Okey, 2007, p. 15; Papić, 1982, pp. 85-90). 
(Papić, 1982, pp. 112-114), the other confessional schools remained in function. While the Muslim schools remained essentially devoted to religious education (Bogićević, 1965, p. 228), the Orthodox schools, which primarily used imported Serbian textbooks, actively propagated Serbian nationalism (Papić, 1978, pp. 118-119).

The Bosnian-Herzegovinian Provincial Government first issued concrete instructions for the organization of the new state schools on 6 July 1879. The ambitious plan, envisaging a compulsory and explicitly secular interconfessional school system as well as state control over confessional schools, was rejected by the Hungarian Minister-President Kálmán Tisza as unrealistic, after which the provincial authorities drafted and accepted a second scheme on 17 August 1880 (Bogićević, 1965, pp. 147-150). The new plan no longer demanded compulsive education, but it still insisted on the interconfessional character of the new schools. According to the authorities, this was the only way to offer Muslim children the western education they could not receive in their confessional schools (Okey, 2007, p. 50).

Considering both the complexity of Bosnia-Herzegovina's ethno-confessional makeup and the heterogeneity of existing South Slavic textbooks, the appropriate choice of textbooks for the regime's new schools proved no simple task. Contemporary Croatian and Serbian textbooks were simply not written with such a diverse readership in mind, which is why they contained numerous texts that were considered offensive by the province's Muslims (Šator, 2004, pp. 103-105). ${ }^{2}$ The authorities nevertheless decided that the schools should at least temporarily use Croatian textbooks, their formally declared advantage being that unlike Serbian textbooks they contained texts both in the Latin and Cyrillic alphabets (Dlustuš, 1894, pp. 100-101).

An initial "Croat-friendly" phase in cultural policy during the first years of Habsburg rule diminished as Magyar influence in Bosnian-Herzegovinian affairs grew, culminating in Benjamin von Kállay's appointment as Austrian-Hungarian Joint Finance Minister and Governor of Bosnia and Herzegovina on 4 June 1882. ${ }^{3}$ Since Magyar politicians considered a pro-Croatian political course dangerous for the Monarchy's dualist system, it was eventually destined to fail (Grčević, 2015, pp. 388-393). Croatian textbooks, already inconvenient because of their religious insensitivities, thus became unfavourable also in terms of their political-ideological content.

The Joint Finance Ministry had enquired as early as February 1883 about the content of history and geography textbooks used in Bosnia and Herzegovina. It decided that the use of problematic Croatian textbooks should cease and that a new range of books suited to Bosnian-Herzegovinian circumstances should be prepared; this was again justified by the need to avoid hurting Muslim sensibilities (Okey, 2007, p. 67). Between the years 1883 and 1893 the authorities issued four readers, one history book and two geography textbooks for the new state primary schools (Dlustuš, 1894, p. 158). Teachers were to teach history exclusively using the monograph and the historical texts printed in the $3^{\text {rd }}$ and $4^{\text {th }}$ grade readers-going beyond the scope of prescribed learning materials was explicitly forbidden (Kraljačić, 1987, p. 256).

2 According to Edina Solak, the committee authorized to check the linguistic adequacy of the new textbooks had concluded that the existing Croatian and Serbian textbooks contained texts that were also offensive towards Jews, Catholics (in the Serbian case) and Orthodox (in the Croatian case) (Solak, 2014, p. 118).

3 Benjamin von Kállay, a Hungarian statesman who ruled the province until his death in 1903, is considered the most important figure in the Habsburg administration of Bosnia and Herzegovina (Okey, 2007, p. 55). T. Kraljačić (1987) remains the classic Yugoslav monograph on the Kállay regime, while R. Okey (2007) may be considered the most referential available English-language synthesis on the Habsburg period in Bosnia and Herzegovina. 
The aforementioned readers and history book represent the primary corpus for the research undertaken in this article, which aims to address the political instrumentalisation of historical education in the Bosnian-Herzegovinian state school system during Habsburg rule. The question of how history was instrumentalised in the textbooks will be approached considering both the selection of historical topics and the manner in which they were utilized in order to impart desirable loyalties and beliefs among the students. The aim of the article is thus not to compare the textbooks' historical narrative with the findings of current historiography; instead, it will attempt to identify the key ideological aspects of the narrative and explain how it proved suitable for furthering the regime's political goals. ${ }^{4}$

\section{"THE LIVES OF OUR ELDERS": FOSTERING A HISTORICALLY-BASED BOSNIAN PATRIOTISM}

The first and most obvious political goal of historical education in the textbooks was the impartment of a historically grounded Bosnian patriotism that, unsurprisingly, was to be rooted in the medieval "golden age". An overbearing focus on medieval Bosnia is already evident in the structure of the history textbook, which offers a synthesis of Bosnian history from antiquity up to the Habsburg occupation. While $24 \%$ of the book was dedicated to 425 years of Ottoman rule, the 283 years of "autonomous" medieval Bosnian history received more than twice as much attention. ${ }^{5}$

The history book not only praised the exploits of medieval rulers and noblemen in order to help construct a historical patriotism and identity, but it also implied that the students should actively mourn their glorious kingdom's fall: "[E]ven today shall every Bosniak patriot shed tears when he remembers the golden crown, his unfortunate last king" (Povijest, 1893, p. 36). ${ }^{6}$ An attempt to spark interest for medieval Bosnian history is noticeable in the readers as well, where the children would read a correspondence between two friends in which one describes to the other a trip he had made with his father to the Sutjeska monastery and the medieval fortress of Bobovac. ${ }^{7}$ A general melancholy pervades passages that bemoan the sorry state of medieval Bosnian architectural heritage at that time. ${ }^{8}$

Even though a later review claimed that the textbooks were supposed to "weaken the impression in some quarters of a 'particular community of interest with neighbouring Slav races'" (Okey, 2007, p. 67), they did not portray medieval Bosnian history in a completely isolationist manner (cf. Kraljačić, 1987, pp. 260-261). The children learnt from the history book that their Slavic forefathers had settled along the Bosna river during the reign of Byzantine emperor Heraclius, as did later their Serbian and Croatian neighbours

\section{- • • •}

4 The methodology of this article was largely inspired by C. Jelavich (1990), which offers an in-depth analysis of the ideological aspects of $19^{\text {th }}$ century textbooks from Croatia and the Kingdom of Serbia.

$562 \%$ of the textbook's content dealt with medieval Bosnian history, spanning from the Slavic migrations in the $7^{\text {th }}$ century to the fall of the Bosnian Kingdom in the 1463. Bosnia's autonomous period ("Bosna je svoja") supposedly began with Kulin Ban's reign in 1180 (Povijest, 1893, p. 15).

6 All English translations from the sources throughout the article are my own.

7 "I know that like myself you also enjoy listening to tales about the lives of our elders, and especially about old Bosnian kings. I have always longed to see those old honourable places from whence they had reigned, where they would convene with their dukes and rule the land" (Treća čitanka, 1893, p. 41).

8 "Today this [Blagaj] is a hamlet, but here was once the capital of Duke Stjepan Kosača.... Today the castle is abandoned, and its black, partly destroyed walls tell how fleeting glory is in this world" (Treća čitanka, 1893 , p. 44). 
(Povijest, 1893, pp. 10-12). The textbook also did not hide the fact that Bosnian territory grew by expanding into neighbouring Croatia or Serbia. Stjepan Kotromanić had thus for instance expanded his state "when he acquired from the strong Croatian counts the counties of Duvno, Livno and Glamoč, which from then on stayed in our homeland" (Povijest, 1893, p. 20).

It is however true that the textbook was to address historical events only relative to their importance for Bosnian history. The Hungarian historian Lajos Thallóczy, reviewing the book's draft in 1891, even explicitly claimed that the Battle of Kosovo should be portrayed with less sympathy than in Serbia (Kraljačić, 1987, p. 255). We may also notice that the readers avoided factually portraying the history of those parts of modern Bosnia that had been included in it only after the Ottoman conquest; the origin of Bihać, a town that had belonged to medieval Croatia, was thus described through a completely ahistorical fairy-tale (Treća čitanka, 1893, pp. 52-54).

Lastly, medieval Bosnian history was supposedly also as a period of high civilizational development: "Bosniaks, then an enlightened nation, which had aspired much towards education, also had their own script, which we call today bosančica. This script was so dear to them that they used it for all their official business" (Treća čitanka, 1893, p. 59). It not only appeared on the peculiar medieval tombstones called stećci, which "were left by the Bogomils or, as the western nations called them, patarens", but remains in use even today by "bey families of old Bosnian origin" (Povijest, 1893, p. 16). As we shall see, both the idea of Bogomilism and Bogomil-Muslim elite continuity would play a crucial role in portraying the history of the Bosnian Muslims.

\section{"THEY BECAME INCLINED TO THE OTTOMANS": THE HISTORY OF BOSNIA'S MUSLIMS}

The Bogomil theory, developed by Croatian historian Franjo Rački, refers to one possible interpretation of the medieval Bosnian Church, considering it dualist and heretical in character (Dautović, 2015, pp. 129-130). The only alternative interpretation in circulation in the late $19^{\text {th }}$ century was that of Serb historian Božidar Petranović, who saw the Church as essentially Eastern Orthodox. ${ }^{9}$ According to the history book, the Bogomils "weren't exactly heathens; but since they ascribed the same power to the devil as to the one and only God, they actually believed in two gods. Priests and hodže, churches and mosques were of no use to them" (Povijest, 1893, p. 16). The book goes on to explain how they were persecuted by the pope and the Hungarian kings, but, being "brave and courageous like lions, yet slick and wise like serpents", they managed to escape persecution by seemingly converting to Catholicism and returning to their original faith once the danger would subside (Povijest, 1893, p. 17).

One of the grave mistakes committed by the last Bosnian king Stjepan Tomašević was supposedly his heavy persecution of the Bogomils in order to gain the pope's backing: "They-some out of revenge, and some because they were more fond of Mohammad's religion—became inclined towards the Ottomans" (Povijest, 1893, p. 36). The Bogomil gen-

9 Modern historiography has largely discredited both the Orthodox interpretation and the use of the epithet "Bogomil" for describing the Bosnian Church. Besides the dualist and Orthodox interpretations, a later "conformist" (pravovjeran) interpretative frame sees the Church as schismatic instead of heretical (Dautović, 2015, pp. 129-131). 
try supposedly secretly helped the Ottomans conquer Bosnia, and "[w]hen the Sultan became the ruler of the land, these nobles converted by and large to the Mohammedan faith, and the Sultan confirmed them the rights and privileges they had always possessed" (Povijest, 1893, p. 42). Mohammedanism thus completely replaced the Bogomil faith after the conquest: "Those who used to be persecuted because of the Bogomil faith became now, after embracing the Mohammedan faith, the masters of the land" (Povijest, 1893, p. 44).

The notion that a clear continuity exists between the medieval Bogomil gentry and the later Muslim elites was widely prevalent in the textbooks. They even claimed that Bosnia fared better under Ottoman rule than other conquered regions because the land had not changed owners. ${ }^{10}$ The Muslim elites supposedly even retained the temperament of the medieval gentry:

These noblemen of ours, for the most part descendants by blood of that old, strong and proud Bosnian gentry, also inherited from it both its good and bad characteristics.... The beys and agas thus completely preserved the old Bosnian virtue of chivalry and heroism! But, on the other

hand, they remained just as unruly and forceful as they used to be (Povijest, 1893, pp. 49-50).

The pronounced presence of both the Bogomil theory and the idea of elite continuity in the textbooks is not at all surprising considering the special role Kállay had assigned the Bosnian Muslims in the construction of the Bosnian nation-they were to be both its core and leading element. According to him, the fact that Muslim landowners were aware of their leading role in the past had made them a "state-forming element par excellence". In the 1890s, he would describe them as "the land's only aristocracy", going as far as to claim they were the only carriers of a state idea in the entire Balkans (Kraljačić, 1987, p. 82).

Although Kállay's concept of Bosnian nationhood appears to share many similarities with how Hungarians understood the Hungarian political nation, the Magyar gentry representing its state-building element (Kraljačić, 1987, p. 83), it remains questionable whether he had actually intended for this identity to grow into a "proper" political nation or simply to serve as a means of fending off Serbian and Croatian nationalism. According to Okey, "its most important function was perhaps to ensure that Bosnian Muslims were not undermined by these claims, and, while not intended for them only, it would serve its purpose if this goal alone were achieved" (Okey, 2007, p. 64). In any case, the Bosnian historical narrative closely followed the template of similar patriotic histories and, as a part of a developing and increasingly popular "repertoire" of Muslim patriotism, endured well into the $20^{\text {th }}$ century (Hajdarpasic, 2015, pp. 181-182). ${ }^{11}$

\section{"NEITHER BETTER NOR WORSE": THE OTTOMAN EMPIRE AND OTHER SENSITIVE TOPICS}

Besides attempting to construct a viable historical narrative for Bosnian Muslim patriotism, the textbooks also showed caution when portraying historical topics Muslims could find offensive. They were even submitted for review to a select group of Muslims in

\footnotetext{
10 "The land largely remained in the same hands as before-only that now the finer and richer nobles called themselves 'beys', and the less fine and rich 'agas'... Since the land mostly did not change masters, neither did thus by and large the state of the peasantry become different under the Turks" (Povijest, 1893, p. 42).

11 As demonstrated in Hajdarpasic, 2015, pp. 161-186, both the Ottoman and Habsburg Empires sponsored "imperial patriotic activities" such as patriotic print media, ethnography or the codification of folk poetry, appropriating thus many "patriotic" practices traditionally considered typical for nationalist activism.
} 
order to make sure their reception among the populace will be positive (Kraljačić, 1987, p. 256). The authorities attempted to accommodate the Muslims by carefully portraying Ottoman history, including the Ottoman-Habsburg wars, and by highlighting their distinguished roles in the Ottoman state.

When examining how the textbooks portrayed the Ottoman Empire, we may notice a tendency to praise its virtues and successes whenever possible. The history book described Osman, the dynasty's progenitor, as "a very wise man and decent hero, who lived and worked his entire life in accordance with how the faith and law of Muhammed taught him" (Povijest, 1893, p. 22). Suleiman II was "the pride and joy of his nation; he and his famous grandfather, Mehmed II, were the greatest and most excellent among so many great and excellent rulers that the Ottomans take pride in" (Povijest, 1893, p. 46). The janissaries were "in that time the greatest army in the world... Sultan Suleiman liked and honoured his Bosnian janissaries the best" (Povijest, 1893, p. 43). ${ }^{12}$

The question of Ottoman violence and tolerance was addressed by historicizing it and framing it into a wider European context. The history book claimed that violent conflict between two nations that would result in pillaging and enslavement used to be standard fare "in the olden days". The Bosnian case was possibly even worse because the adversaries were also divided by religion: "Still, when we compare the Ottomans to other victorious nations, we must admit that they were neither better nor worse than many of them" (Povijest, 1893, p. 41). Discriminatory Ottoman tolerance was juxtaposed with religious violence and intolerance in early modern Europe:

[T]he Christian rulers themselves would not tolerate other religion in their states besides their own. The Turkish sultans-even if they did not allow their subjects (Christians) to raise belltowers or build churches-at least did not prevent them from serving God and performing religious rites in their own custom;... The Mohammedans were however still the masters and the Christians the reaya; the Christian community was thus unhappy, and lots of them would move out of our homeland and the rest of the Turkish Empire, most of whom would settle the [Habsburg] Emperor's lands (Povijest, 1893, pp. 44-45).

Another topic that could arouse controversy were the Ottoman-Habsburg wars, which the history book portrayed mostly as a battle between two equal foes. Ottoman military prowess thus supposedly reflected itself in the fact that the Habsburgs, "despite all of their great strength, could not fend them off for a long time" (Povijest, 1893, p. 46). The readers also offered the children vivid descriptions of the wars through the decasyllabic epic poetry of $18^{\text {th }}$ century Dalmatian writer Andrija Kačić Miošić. While some of the traditional epic folk poems in Croatian textbooks had to be censored for use in Bosnian-Herzegovinian schools because of their offensive content (Šator, 2004, pp. 104-105), the poetry of Kačić Miošić portrayed the Ottoman side in a curiously unbiased, sometimes even empathic manner. ${ }^{13} \mathrm{He}$ chronicled Ottoman territorial loses during the Great Turkish War from the Sultan's viewpoint and his descriptions of Prince Eugen of Savoy's destruction

\section{-....}

12 The textbook goes on to describe the Sultan's love for the Bosniaks: »[He] would appoint local sons for captains in the fortresses he would raise on the Hungarian, Dalmatian and now Montenegrin border throughout Bosnia. However, Suleiman showed how the Bosniaks were dear to him the most by appointing as teacher to his son and heir the valiant courtier of Bosniak origin Sokol [Mehmed-paša Sokolović], who would be later celebrated as the Grand Vizier of three sultans « (Povijest, 1893, p. 43).

13 Andrija Kačić Miošić (1704-1760) was the author of the immensely popular vernacular literary work Razgovor ugodni naroda slovinskoga (1756), part of which focuses on the Christian-Ottoman wars. Despite containing the usual assortment of negative anti-Turkish stereotypes, it still stands out as unusually tolerant compared to contemporary works. The author, who tended to view war as a stage for the exhibition of heroism, was particularly sympathetic to Bosnian Muslim heroes because of their Slavic ethnicity (Dukić, 2004, pp. 175-178). 
of Sarajevo were especially full of sympathy for the once glorious town's plight (Četvrta čitanka, 1912, pp. 81-84). ${ }^{14}$

Lastly, the history book dubbed the last century of Ottoman rule "the period of rebellion", chronicling the various revolts against the central authorities and their laudable but ultimately unsuccessful reform efforts in the $19^{\text {th }}$ century. Thallóczy recommended that a character of national uprising be given to the Muslim feudal resistance against the Sultan, thus making Habsburg occupation appear to be the logical next step. Particular attention was to be paid to Husein Gradaščević, whose uprising could serve as proof that the Muslim nobles were the first to rebel against the Ottomans (Kraljačić, 1987, pp. 253-254). The history book indeed described this rebellion in great detail, stating that the Emperor asked the Sultan to be merciful towards Gradaščević, who had fled to Habsburg Slavonia (Povijest, 1893, p. 51). The children also read about the subjugation of the janissaries and feudal elites in two texts from the readers, one of which was an epic folk song written down by the famous Franciscan Ivan Frano Jukić (Četvrta čitanka, 1912, pp. 84-85). ${ }^{15}$ Both texts spoke of mutiny against imperial authority in a critical manner.

\section{"THE HABSBURGS, AS HUNGARIAN KINGS": LEGITIMIZATION AND PORTRAYAL}

The final topic to be addressed concerns the historic portrayal of the Habsburg dynasty and the legitimization of its contemporary rule of Bosnia and Herzegovina. While the dynasty was portrayed using mostly the same texts as in other Habsburg textbooks, the legitimacy of their rule was justified based on Bosnian-Hungarian historical ties and supported by the putative benefits a population may reap from a foreign government's civilizing mission.

The children would read in the fourth reader three consecutive texts on the lives and great deeds of Maria Theresia, Joseph II and Franz II (Četvrta čitanka, 1912, pp. 86-91). These texts, along with those portraying contemporaries such as Emperor Franz Joseph, were part of a general assortment of patriotic Habsburg texts present in all Austrian textbooks and constitute a kind of Habsburg educational "canon" (Bruckmüller, 2007). The history book however offered only the most rudimentary information on the "famous ruling house of Habsburg" (Povijest, 1893, p. 45), focusing mostly on their wars with the Ottomans. It claimed that ever since the Treaty of Sistova concluded the last Austro-Turkish War in 1791, "the emperors in Vienna and the sultans in Istanbul would always get along and look out for each other like good neighbours and honest friends" (Povijest, 1893, p. 48).

The history book also stated that "[t]he Habsburgs, as Hungarian kings, did not forget that Bosnia had belonged to the crown of St. Stephen since ancient times" (Povijest, 1893, p. 46). We may indeed notice in the book a strong emphasis on historical ties with Hungary, the narrative abounding with anecdotes of mutual support and cooperation. For example, Sigismund of Luxemburg supposedly accepted the Bosnian gentry "so nicely and with such honours that even nowadays it is remembered and spoken of how the Hungarian king accepted and was a host to the Bosnian lords in his white Buda " (Povijest, 1893, p. 50). While we may see in this emphasis on relations with Hungary an at-

\footnotetext{
14

"Koliko je pusto Sarajevo, / šeher b’jeli gnj'ezdo trgovačko, / svega ga je princip osvojio, / sa četiri strane užegao. [Oh, how desolate is Sarajevo, / white city, nest of trade, / the prince conquered it whole / and burned it from all four sides.] « (Četvrta čitanka, 1912, p. 84).

15 The first text was a general description of the history of Sarajevo (Treća čitanka, 1893, p. 40).
} 
tempt to justify a possible later Hungarian annexation of Bosnia and Herzegovina on the grounds of historical right, the primary objective of it was more likely to have been the historic legitimization of Habsburg rule. Although Kállay, like many other Hungarian politicians, might have been privately sympathetic to Hungarian claims over Bosnia and Herzegovina, his main political goal as Joint Finance Minister was keeping the province inside the Monarchy and maintaining its dualist system in balance (Kraljačić, 1987, pp. 95-99).

Lastly, Habsburg rule was also implicitly justified by the Empire's putative civilizing mission in Bosnia and Herzegovina. In fact, this was not the first time a foreign power had brought peace and prosperity to Bosnia's unruly populace. The textbook's descriptions of Roman Illyricum thus transposed into the past an idealized narrative of contemporary Habsburg rule:

The Illyrians, even though they long resisted the Romans with all of their might, were very fortunate to have fallen under the lordship of the Romans, because the Romans not only established peace and order in the land, but it also did not take long for it to bloom to such an extent that it never could have had the Illyrians remained their own masters.... The Romans immediately began to build beautiful roads in our homeland, whose traces remain even today, to erect towns where trade and crafts flourished; and to extract ores as well (Povijest, 1893, pp. 6-7).

The history book seemed to have given the children a general impression that the past was inevitably characterised by religious injustice, intolerance and violence-such a stance was already visible in the aforementioned descriptions of warfare in the past. While all three religions now supposedly lived in peace as children of the same Bosnian homeland, "[i]t was not always so, children, and lots of suffering had to pass, much blood had to be spilt until it would come to this!" (Povijest, 1893, p. 44). Describing the Ottoman reform efforts as failed and mentioning the bloody Herzegovinian uprising of 1875, the book optimistically concluded that "finally cometh the year 1878, when a dawn of a nicer era and a happier future broke for our homeland under the benevolent ruler, our most gracious Emperor and King Franz Joseph I" (Povijest, 1893, p. 52).

\section{CONCLUSION}

The article has shown that historical education in Bosnian-Herzegovinian primary schools was instrumentalised in order to serve three primary political goals, the first of which was the fostering of a historically based Bosnian patriotism. The textbooks attempted to arouse the children's interest for medieval Bosnian nobles, rulers and historical sights, while at the same time encouraging them to identify with the glorious deeds of their putative forefathers. Their Bosnian-centred historical narrative, with its emphasis on a supposed medieval "golden age", thus hardly stands out in comparison to other South Slavic or European nationalist narratives of that time.

The second notable political goal of historical education was the accommodation of the Muslims and their elites. This was reflected both in the caution with which the textbooks approached historical topics that were potentially offensive to Muslims and in their appreciative portrayal of the Muslim elites, the supposed descendants of the medieval Bosnian gentry. Considering both the role assigned to Muslims in Bosnian nation-building and the fact that primary education only became compulsory as late as 1911 (Bogićević, 
1965, pp. 142-144), the regime most likely considered it of upmost importance to eliminate any possible objections Muslim parents may have had against sending their children to state schools.

The last political goal pursued in the schools was the legitimization of contemporary Habsburg rule over Bosnia and Herzegovina. The textbooks justified Habsburg rule both on the grounds of Bosnia's historical relations with the Kingdom of Hungary and by implicitly arguing that a foreign benevolent government may benefit a divided and rebellious population. They would regularly juxtapose a violent, intolerant and unfair past with a peaceful, egalitarian and just present, for which the people of Bosnia and Herzegovina obviously had to thank their new Habsburg rulers.

The extent to which the state schools had actually managed to disseminate their historical narrative likely remained lacklustre-the province's network of primary schools was both severely underdeveloped and non-compulsory throughout most of the Habsburg period. ${ }^{16}$ It should however be noted that the key characteristics of the historical narrative described in this article were not only resurrected after the establishment of an independent Bosnia and Herzegovina in the 1990s (Hajdarpasic, 2015, p. 257, f. 89), but largely remain typical components of Bosniak nationalist history even today. ${ }^{17} \mathrm{We}$ may thus conclude that the Habsburg state school system in Bosnia and Herzegovina was the first attempt at an institutionalized mass dissemination of a modern and historically backed Bosnian patriotism and that it definitely played an important role in its spread and development. The long-term influence it had exerted on the development of a "new repertoire of Muslim patriotism" (Hajdarpasic, 2015, p. 182) should thus not be underestimated.

\section{BIBLIOGRAPHY}

Bogićević, V. (1965). Istorija razvitka osnovnih škola u Bosni i Hercegovini: U doba turske i austrougarske uprave: (1463-1918). Sarajevo: Zavod za izdavanje udžbenika BiH.

Bruckmüller, E. (2007). Patriotic and national myths: National consciousness and elementary school education in imperial Austria. In L. Cole \& D. Unowsky (Eds.), The limits of loyalty: Imperial symbolism, popular allegiances, and state patriotism in the late Habsburg monarchy. New York, NY: Berghahn Books. (Austrian and Habsburg Studies, 9).

Četvrta čitanka za osnovne škole u Bosni i Hercegovini. (1912). Sarajevo: Zemaljska štamparija.

Ćurić, H. (1983). Muslimansko školstvo u Bosni i Hercegovini do 1918. godine. Sarajevo: Veselin Masleša.

Dautović, D. (2015). Crkva bosanska: Moderni historiografski tokovi, rasprave i kontroverze (2005-2015). Historijska traganja, 2015(15), 127-160.

\section{$\cdots \cdots$}

16 According to Kraljačić, only $12.96 \%$ of children of school age were visiting primary (including confessional) schools in the school year 1899/1900. The percentage of children visiting any kind of primary school in that year was $12.91 \%$. The percentages of children visiting school by religion are $5.94 \%$ for Muslim children, $12.96 \%$ for Orthodox children, $21.86 \%$ for Catholic children, $63.83 \%$ for Jewish children and $70.12 \%$ for "other" children (Kraljačić, 1987, p. 258).

17 M. Oršolić, (2017) offers a journalistic analysis of the myths present in the nationalist works of authors such as Muhamed Filipović, Mustafa Imamović and Enver Imamović. 
Dlustuš, L. (1894). Školske prilike u Bosni i Hercegovini od okupacije do danas. Školski vjesnik, 1(1-10), 1-4, 50-54, 100-106, 155-161, 223-227, 289-293, 341-343, 401404, 455-458, 531-538.

Dukić, D. (2004). Sultanova djeca: Predodžbe Turaka u hrvatskoj književnosti ranog novovjekovlja. Zadar: Thema.

Grčević, M. (2015). Vanjskopolitički utjecaji na hrvatski književnojezični razvoj u drugoj polovici XIX. stoljeća. In I. Šestak (Ed.), Od Mure do mora, od Save do Seine: Spomenzbornik patru Vladimiru Horvatu SJ za njegov 80. rođendan. Zagreb: Filozofsko-teološki institut Družbe Isusove.

Hajdarpasic, E. (2015). Whose Bosnia?: Nationalism and political imagination in the Balkans, 1840-1914. New York, NY: Cornell University Press. https://doi.org/10.7591/cornell/9780801453717.001.0001

Jelavich, C. (1990). South Slav nationalisms: Textbooks and Yugoslav Union before 1914. Columbus: Ohio State University Press.

Kraljačić, T. (1987). Kalajev režim u Bosni i Hercegovini: 1882-1903. Sarajevo: Veselin Masleša.

Okey, R. (2007). Taming Balkan nationalism: The Habsburg 'Civilizing Mission' in Bosnia, 1878-1914. New York, NY: Oxford University Press Inc. https://doi.org/10.1093/acprof: oso/9780199213917.001.0001

Oršolić, M. (2017, November 9). Bošnjački nacionalni mitovi. Retrieved December 13, 2017, from http://www.prometej.ba/clanak/drustvo-i-znanost/bosnjacki-nacionalni-mitovi-3426

Papić, M. (1972). Školstvo u Bosni i Hercegovini za vrijeme austro-ugarske okupacije (1878-1918). Sarajevo: Veselin Masleša.

Papić, M. (1978). Istorija srpskih škola u Bosni i Hercegovini. Sarajevo: Veselin Masleša.

Papić, M. (1982). Hrvatsko školstvo u Bosni i Hercegovini do 1918. godine. Sarajevo: Veselin Masleša.

Povijest Bosne i Hercegovine za osnovne škole. (1893). Sarajevo: Zemaljska štamparija.

Solak, E. (2014). Rasprave o jeziku u Bosni i Hercegovini od 1850. do 1914. godine. Sarajevo: Institut za jezik.

Šator, M. (2004). Bosanski, hrvatski, srpski jezik u BiH do 1914. godine. Mostar: Univerzitet "Džemal Bijedić" Mostar: Fakultet humanističkih nauka.

Treća čitanka za osnovne škole u Bosni i Hercegovini. (1893). Sarajevo: Zemaljska štamparija. 